OPEN ACCESS

Edited by:

Fabio R. Marin

University of São Paulo, Brazil

Reviewed by: Jing Wang,

China Agricultural University, China Pantazis Georgiou, Aristotle University of Thessaloniki, Greece

*Correspondence:

Meisam Nazar

Meisam.nazari@

forst.uni-goettingen.de;

Meisam.nazari1991@gmail.com

Specialty section:

This article was submitted to Agroecological Cropping Systems, a section of the journa Frontiers in Agronomy

Received: 31 October 2021 Accepted: 29 November 2021 Published: 20 December 2021

Citation: Nazari M, Mirgol B and Salehi H (2021) Climate Change Impact Assessment and Adaptation Strategies for Rainfed Wheat in Contrasting Climatic Regions of Iran. Front. Agron. 3:806146 doi: 10.3389/fagro.2021.806146

\section{Climate Change Impact Assessment and Adaptation Strategies for Rainfed Wheat in Contrasting Climatic Regions of Iran}

\author{
Meisam Nazari ${ }^{1 *}$, Behnam Mirgol ${ }^{2}$ and Hamid Salehi ${ }^{3}$ \\ ${ }^{1}$ Division of Biogeochemistry of Agroecosystems, Georg-August University of Göttingen, Göttingen, Germany, ${ }^{2}$ Center for \\ Agroecology, Water and Resilience, Coventry University, Coventry, United Kingdom, ${ }^{3}$ Department of Water Engineering, \\ Tarbiat Modares University, Tehran, Iran
}

This is the first large-scale study to assess the climate change impact on the grain yield of rainfed wheat for three provinces of contrasting climatic conditions (temperate, cold semi-arid, and hot arid) in Iran. Five integrative climate change scenarios including $+0.5^{\circ} \mathrm{C}$ temperature plus $-5 \%$ precipitation, $+1{ }^{\circ} \mathrm{C}$ plus $-10 \%,+1.5^{\circ} \mathrm{C}$ plus $-15 \%$, $+2^{\circ} \mathrm{C}$ plus $-20 \%$, and $+2.5^{\circ} \mathrm{C}$ plus $-25 \%$ were used and evaluated. Nitrogen fertilizer and shifting planting dates were tested for their suitability as adaptive strategies for rainfed wheat against the changing climate. The climate change scenarios reduced the grain yield by -6.9 to $-44.8 \%$ in the temperate province Mazandaran and by -7.3 to $-54.4 \%$ in the hot arid province Khuzestan but increased it by $+16.7 \%$ in the cold semi-arid province Eastern Azarbaijan. The additional application of $+15,+30$, +45 , and $+60 \mathrm{~kg} \mathrm{ha}^{-1}$ nitrogen fertilizer as urea at sowing could not, in most cases, compensate for the grain yield reductions under the climate change scenarios. Instead, late planting dates in November, December, and January enhanced the grain yield by +6 to $+70.6 \%$ in Mazandaran under all climate change scenarios and by +94 to $+271 \%$ in Khuzestan under all climate change scenarios except under the scenario $+2.5^{\circ} \mathrm{C}$ temperature plus-25\% precipitation which led to a grain yield reduction of $-85.5 \%$. It is concluded that rainfed wheat production in regions with cold climates can benefit from the climate change, but it can be impaired in temperate regions and especially in vulnerable hot regions like Khuzestan. Shifting planting date can be regarded as an efficient yield-compensating and environmentally friendly adaptive strategy of rainfed wheat against the climate change in temperate and hot arid regions.

Keywords: climate change, nitrogen, planting date, precipitation, rainfed wheat, temperature

\section{INTRODUCTION}

Climate remarkably affects crop production and causes roughly a third of yield fluctuations worldwide (Ray et al., 2015). Climate warming may substantially impact on crop production in farmlands (Challinor et al., 2014). Predictions show that global mean temperatures will increase by $+0.5^{\circ} \mathrm{C}$ to $+4^{\circ} \mathrm{C}$ by the end of the twenty-first century (Hartmann et al., 2013). In addition, global annual precipitation amounts are projected to change by -30 to $+14 \%$, depending on the methods 
and scenarios used (Vallam and Qin, 2018; Rojas et al., 2019). Crop production is negatively associated with increased temperatures and reduced precipitation amounts at field, country, and global scales (Tao et al., 2008; Schlenker and Lobell, 2010; Lobell et al., 2011; Sakurai et al., 2011; Ray et al., 2015; Mirgol and Nazari, 2018). Despite numerous proofs for the impact of climate change on crop production, evidence on the impact is lacking in the hotspot of climate warming, the Middle East (Evans, 2009). Thus, it is necessary to predict the impact of climate change on crop production in the Middle East (Lobell et al., 2008; Urwin and Jordan, 2008).

Climate change increases the frequency of extreme heat events (Ortiz et al., 2008; Teixeira et al., 2013). Generally, increased mean temperatures accelerate the rate of crop development and shorten the crop's growing season length (Siebert and Ewert, 2012; Eyshi Rezaei et al., 2017). Moreover, heat stress around the reproductive phase of cereals can significantly decrease the grain yield (Eyshi Rezaei et al., 2015). Hence, devising adaptation strategies to climate change that can extend the growing season length but also escape from the heat stress is necessary.

Process-based crop models are extensively used for assessing cropping systems responses to climate change and various management strategies (Parry et al., 2004; Deihimfard et al., 2015). Therefore, crop models can be very valuable tools for farmers and decision makers (McNunn et al., 2019). An assemblage of 29 crop models indicated that the yield of wheat (Triticum aestivum L.) worldwide is declined by $-5 \%$ in response to $+1^{\circ} \mathrm{C}$ increase in the global temperature (Liu et al., 2016).

Iran is a country of diverse climatic conditions including humid northern areas, cold northwestern areas, and dry eastern and southern areas, which are vulnerable to climate warming (Abbaspour et al., 2009). Wheat is one of the major crops in the world and the main cereal crop in Iran (Eyshi Rezaie and Bannayan, 2012). About $65 \%$ of farmlands in Iran are under rainfed wheat production, contributing to roughly $35 \%$ of wheat production of the country (Nassiri et al., 2006). It is anticipated that demand for wheat in Iran would increase in the future (Nazari Nooghabi et al., 2020). However, mismanagement and precipitation anomalies in Iran lead to reduced wheat yield (Faramarzi et al., 2010; Nouri et al., 2017a).

An investigation of 32 climatic stations in different regions of Iran indicated a significantly increasing trend in annual mean and maximum temperatures as well as in reference crop evapotranspiration from 1960 to 2005 (Dinpashoh et al., 2011; Saboohi et al., 2012; Kousari et al., 2013). An assemblage of five climatic models projected maximum daily temperature increases of $+1.1^{\circ} \mathrm{C}$ to $+2.75^{\circ} \mathrm{C}$ and annual precipitation reductions of about 0 to $-25 \%$ across Iran for the future decades (Vaghefi et al., 2019). Moreover, Iran's agroecosystems encountered severe drought events within the recent decades (Foltz, 2002). It is predicted that Iran's agroecosystems would face more drought events in the future, leading to limited water resources (Sayari et al., 2015).
The response of crop production to climate change in Iran has been assessed in a set of studies. It is predicted that wheat yield would decrease by -5 to $-50 \%$ due to climate change in various regions of Iran (Bannayan and Eyshi Rezaei, 2014; Valizadeh et al., 2014; Maddah et al., 2015; Mirgol et al., 2020). Furthermore, the yield of maize (Zea mays L.), potato (Solanum tuberosum L.), and chickpea (Cicer arietinum L.) would decline by $-40 \%$ in different regions of the country (Hijmans, 2003; Lashkari et al., 2012; Moradi et al., 2013; Hajarpoor, 2014). However, these studies were region-specific and there is so far only one country-wide study on the response of maize to climate warming (Eyshi Rezaei and Lashkari, 2019). Studies on the potential impact of climate change on the production of other important crops like wheat in contrasting climatic regions of Iran are lacking. In addition to this, there is little information on the optimum planting date and nitrogen fertilizer quantity for crop production under climate change in Iran. Investigating the impact of climate change on such a strategic crop for Iran as wheat and devising optimum adaptation strategies for rainfed wheat production in the contrasting climatic regions of the country are particularly important.

This study had two aims. The first aim was to predict the grain yield of rainfed wheat in three provinces of Iran with contrasting climatic conditions under different climate change scenarios. The second aim was to assess the impacts of different nitrogen fertilizer application rates and planting dates for compensation of the negative impacts of climate change on the grain yield. Climate, soil, and management data were attained from several global and national datasets for adjusting and performing the crop model.

\section{MATERIALS AND METHODS}

\section{Study Area}

The study area included three provinces of Iran with contrasting climatic conditions namely Mazandaran, Eastern Azarbaijan, and Khuzestan (Figure 1). Mazandaran, covering an area of $23,833 \mathrm{~km}^{2}$, is located in the south of the Caspian Sea and has diverse natural features such as plains, grasslands, mountains, and forests. Eastern Azarbaijan is located in the northwest of Iran and has an area of $47,830 \mathrm{~km}^{2}$. The climate of Eastern Azarbaijan is influenced by the Mediterranean climate. Khuzestan is located in the south west of Iran and covers an area of $64,055 \mathrm{~km}^{2}$. In general, the climate of Khuzestan is hot but it may be cold and dry in winter. Mazandaran, Eastern Azarbaijan, and Khuzestan contribute to 20\% (900,000 ha) of Iran's rainfed wheat production. Iran has 31 provinces, each contributing its share to the rainfed wheat production of the country. However, the contribution of these three provinces is more than the other ones. Furthermore, the climate of these provinces completely differs from each other and represent also the climate of the provinces nearby, giving good insights into the climate change impact on rainfed wheat over contrasting climatic conditions in Iran and also in globally similar areas. Spatial patterns of mean temperature 


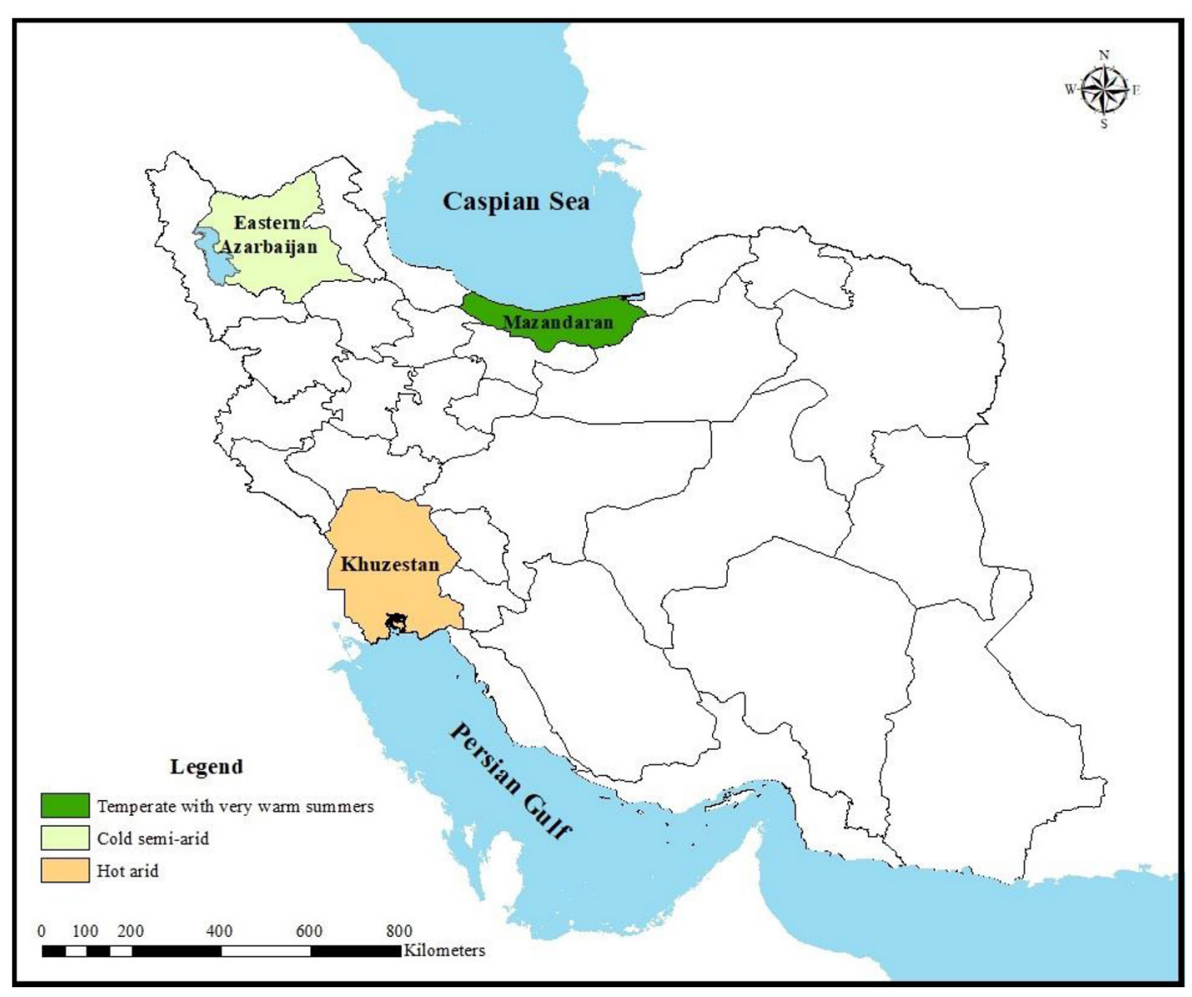

FIGURE 1 | Geographic situation and climate type of the provinces Mazandaran, Eastern Azarbaijan, and Khuzestan of Iran classified based on the updated Köppen-Geiger classification system (Kottek et al., 2006).

and mean annual precipitation (obtained from AgMERRA dataset) as well as plant available water capacity (obtained from IGBP-DIS dataset) for the period 1980-2010 are presented in Figure 2.

\section{Crop Model}

The crop model Agricultural Production Systems sIMulator (APSIM) version 7.10 (Holzworth et al., 2014) was used to evaluate the rainfed wheat yield of the provinces under different climate change and management scenarios. APSIM is an internationally reputable process-based biophysical model for simulation of agricultural systems. APSIM is widely used to evaluate the ecological and economic outcomes of management practices under climate change. It has a set of modules capable of simulating the influence of climate, soil, plant, animals, and various management factors on crop development and yield as well as on soil and water properties. For running the APSIM model, input data including climatic data (i.e., temperature and precipitation), soil data (i.e., soil organic carbon and plant available water capacity), cultivar parameters (e.g., genetic coefficients and phenology), and management information (e.g., fertilizer application and planting date) are required.

\section{Data Preparation}

The climatic data daily maximum and minimum temperatures, precipitation, and solar radiation were attained from the
AgMERRA climate dataset for agricultural modeling (Ruane et al., 2015). The AgMERRA dataset has been specifically developed for crop modeling objectives based on field and satellite observations (Rienecker et al., 2011). The dataset was grid-based at the global scale $\left(0.5^{\circ} \times 0.5^{\circ}\right.$ resolution $)$ for the period 1980-2010. The grid cells of the studied provinces were extracted from the global dataset. We used climate change scenarios instead of RCP (Representative Concentration Pathway) scenarios due to the large-scale and grid-based structure of this study (Giannakopoulos et al., 2009; Liu et al., 2016; Eyshi Rezaei and Lashkari, 2019).

The soil data (at $0-100 \mathrm{~cm}$ depth) bulk density, field capacity, plant available water capacity, carbon density, total nitrogen density, and wilting point at $0.5^{\circ} \times 0.5^{\circ}$ resolution were acquired from the Global Gridded Surfaces of Selected Soil Characteristics dataset (Batjes, 1995). The global observations were interpolated to a global grid-based system using statistical bootstrapping (Batjes, 1995). Other soil properties required by APSIM such as initial surface crop residue, carbon to nitrogen ratio of the initial surface crop residue, soil carbon to nitrogen ratio, texture, and $\mathrm{pH}$ were obtained by questionaries provided to the agricultural research centers in each province. The questionaries also included management parameters such as planting date, planting density, planting depth, and fertilizer application rate. Sardari is a very common rainfed winter wheat cultivar grown throughout Iran (Nassiri et al., 2006). Therefore, the already 

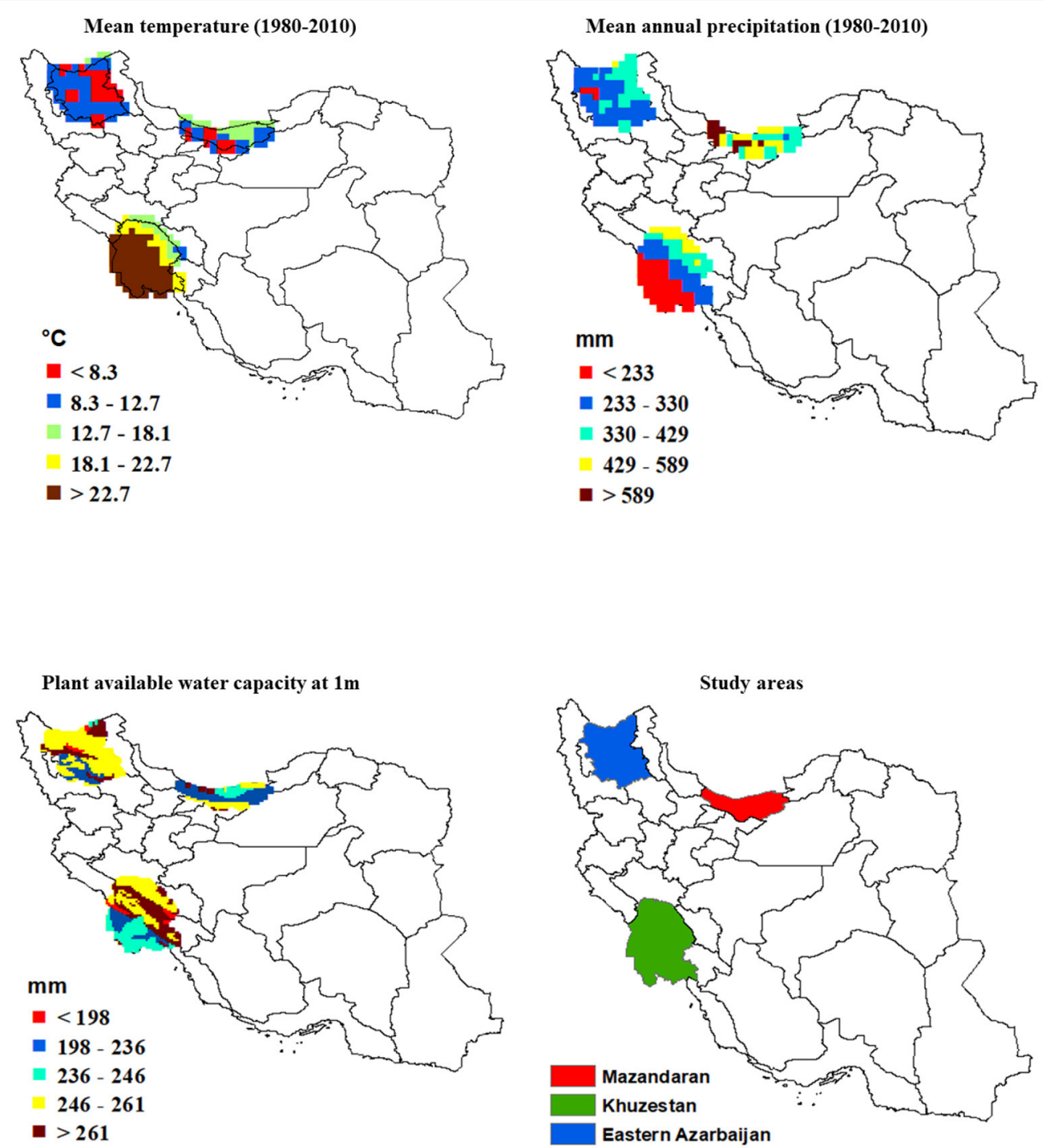

FIGURE 2 | Spatial patterns of mean temperature and mean annual precipitation (obtained from AgMERRA dataset) and plant available water capacity (obtained from IGBP-DIS dataset) for the period 1980-2010.

calibrated and validated genetic coefficients of Sardari cultivar (Table 1, Bannayan et al., 2014) were used for simulation of the cultivar. Some major soil and management parameters used in the study are provided in Table 2 .

\section{Climate Change, Nitrogen Fertilizer, and Planting Date Scenarios}

The impact of climate change on yield and growing season of rainfed wheat was evaluated by running the crop model with the baseline daily maximum and minimum temperatures and precipitation (1980-2010) and five levels of integrative climate change scenarios: $+0.5^{\circ} \mathrm{C}$ temperature plus $-5 \%$ precipitation, $+1^{\circ} \mathrm{C}$ plus $-10 \%,+1.5^{\circ} \mathrm{C}$ plus $-15 \%,+2^{\circ} \mathrm{C}$ plus $-20 \%$, and $+2.5^{\circ} \mathrm{C}$ plus $-25 \%$. Four levels of nitrogen fertilizer as urea including baseline fertilizer $+15 \mathrm{~kg} \mathrm{ha}^{-1}$, baseline fertilizer $+30 \mathrm{~kg} \mathrm{ha}^{-1}$, baseline fertilizer $+45 \mathrm{~kg} \mathrm{ha}^{-1}$, and baseline fertilizer $+60 \mathrm{~kg} \mathrm{ha}^{-1}$ were applied at sowing. There were four planting dates including 1 month before the baseline planting date, 1 month after baseline planting date, 2 months after baseline planting date, and 3 months after baseline planting date. $\mathrm{CO}_{2}$ fertilization effect was not considered in the present study, due to its small impact on wheat grain yield under low input rainfed conditions (Mitchell et al., 1993; Anwar et al., 2007; Degener, 2015; Nouri et al., 2017a).

\section{Model Evaluation}

The performance of the crop model in simulating the rainfed wheat grain yield was evaluated by the root mean square error (RMSE). The grain yields simulated by the model were compared to the observed grain yields for each province (Agricultural Ministry of Iran., 2010). RMSE is an indicator of the error of crop 
TABLE 1 | Genetic coefficients of Sardari wheat cultivar (Adopted from Bannayan et al., 2014).

\begin{tabular}{lcccc}
\hline P1V & P5 & G1 & G2 & G3 \\
\hline 1 & 450 & 13 & 41 & 1.5 \\
\hline
\end{tabular}

P1V, days needed to complete vernalization; $P 5$, duration of grain filling phase $\left({ }^{\circ} \mathrm{C}\right.$ days); G1, kernel number per unit canopy weight at anthesis; G2, kernel size (mg); G3, dry weight (including grain) of a single tiller at maturity $(g)$.

models, measuring high errors (Brisson et al., 2002):

$$
R M S E=\left[n^{-1} \sum_{i=1}^{n}\left(S_{i}-O_{i}\right)^{2}\right]^{0.5}
$$

where $S_{i}$ is the simulated yield; $\mathrm{O}_{\mathrm{i}}$ is the observed yield; and $\mathrm{n}$ is the number of observations.

\section{RESULTS}

\section{Performance of the Crop Model}

The simulated and observed grain yields were plotted against each other in each province and across the provinces for the period 2006-2010 (Figure 3). The APSIM model precision was reasonably well for each province, being highest for the province Khuzestan with $0.17 \mathrm{t} \mathrm{ha}^{-1}$ error in simulating the grain yield and being lowest for the province Eastern Azarbaijan with the simulation error of nearly $0.30 \mathrm{t} \mathrm{ha}^{-1}$. Across the provinces, APSIM was able to simulate the grain yield reasonably well $\left(R^{2}=0.79\right.$, RMSE $=0.24$ $\left.\mathrm{tha}^{-1}\right)$.

\section{Climate Change Impact on the Growing Season Length and Grain Yield}

The climate change scenarios decreased the growing season length of rainfed wheat in the temperate province Mazandaran ( -5 to -176 days) and cold semi-arid province Eastern Azarbaijan ( -5 to -25 days) more dramatically compared to that in the hot arid province Khuzestan ( -3 to -23 days) (Figure 3). In all provinces, the lowest and highest declines in the growing season length were attributed to the climate change scenarios $+1^{\circ} \mathrm{C}$ temperature plus $-10 \%$ precipitation and $+2.5^{\circ} \mathrm{C}$ temperature plus $-25 \%$ precipitation, respectively.

The climate change scenarios considerably declined the grain yield of rainfed wheat in the provinces Mazandaran and Khuzestan, but, in general, moderately increased the grain yield in the province Eastern Azarbaijan (Figure 4). Change in the grain yield under the different climate change scenarios ranged from -6.9 to $-44.8 \%$ in Mazandaran, -7.3 to $-54.4 \%$ in Khuzestan, and -0.2 to $+16.7 \%$ in Eastern Azarbaijan. In all provinces, the lowest and highest changes in the grain yield were attributed to the scenarios $+1^{\circ} \mathrm{C}$ temperature plus $-10 \%$ precipitation and $+2.5^{\circ} \mathrm{C}$ temperature plus $-25 \%$ precipitation, respectively.

\section{Impacts of Nitrogen Fertilizer Application on the Grain Yield}

The scenarios of nitrogen fertilizer application had no effect on the grain yield under the climate change scenarios in the cold semi-arid province Eastern Azarbaijan and hot arid province Khuzestan (Figure 5). However, neglectable grain yield reductions $(-0.02 \%)$ were caused by further application nitrogen fertilizer under the climate change scenario $+2.5^{\circ} \mathrm{C}$ temperature plus $-25 \%$ precipitation in the province Khuzestan. In the temperate province Mazandaran, the nitrogen fertilizer scenarios slightly decreased the grain yield $(-4.1 \%)$ under the climate change scenario $+1{ }^{\circ} \mathrm{C}$ temperature plus $-10 \%$ precipitation. Moreover, the grain yield was mildly increased by +9.1 , +6.7 , and $+4.7 \%$ through the application of 15 , 30 , and $45 \mathrm{~kg}$ more nitrogen fertilizer, respectively, and was moderately decreased $(-15.4 \%)$ through the application of $60 \mathrm{~kg}$ more nitrogen fertilizer under the climate change scenario $+2.5^{\circ} \mathrm{C}$ temperature plus $-25 \%$ precipitation. Furthermore, under the baseline climate conditions, the nitrogen fertilizer scenarios slightly decreased $(-4.3 \%)$ and increased $(+7.3 \%)$ the grain yield in the provinces Mazandaran and Khuzestan, respectively. The grain yield was remarkably increased $(+44.9$ to $+97.3 \%)$ by the addition of 30,45 , and $60 \mathrm{~kg}$ more nitrogen fertilizer under the baseline climate in the province Eastern Azarbaijan.

\section{Impacts of Planting Date on the Grain Yield}

In the temperate province Mazandaran, late planting in November, December, and January remarkably increased the grain yield by +4.2 to $+48.2 \%$ under the baseline climatic conditions and climate change scenarios in comparison to the baseline planting date in October (Figure 6). Early planting in September led to -4.1 , -4.4 , and $-23.3 \%$ reduction in the grain yield under the climate change scenarios $+1^{\circ} \mathrm{C}$ temperature plus $-10 \%$ precipitation, baseline, and $+2.5^{\circ} \mathrm{C}$ temperature plus $-25 \%$ precipitation.

In the cold semi-arid province Eastern Azarbaijan, late planting in November increased the grain yield by +15.3 to $+18.8 \%$ under the baseline climatic conditions and the climate change scenarios $+0.5^{\circ} \mathrm{C}$ temperature plus $-5 \%$ precipitation and $+1{ }^{\circ} \mathrm{C}$ temperature plus $-10 \%$ precipitation, but reduced it by -10.4 to $-18.1 \%$ under the other climate change scenarios. The highest grain yield decline $(-100 \%)$ was attributed to planting in January under the climate change scenarios $+2{ }^{\circ} \mathrm{C}$ temperature plus $-20 \%$ precipitation and $+2.5^{\circ} \mathrm{C}$ temperature plus - $25 \%$ precipitation.

In the hot arid province Khuzestan, late planting in November, December, and January led to a grain yield enhancement of +58.3 to $+271 \%$ under the baseline climatic conditions and all climate change scenarios except under the scenario $+2.5{ }^{\circ} \mathrm{C}$ temperature plus $25 \%$ precipitation. Late planting in November, December, and January reduced the grain yield by $-85 \%$ under the climate change scenario $+2.5{ }^{\circ} \mathrm{C}$ temperature plus $25 \%$ precipitation. 
TABLE 2 | Major soil and management parameters of the studied provinces obtained from the global and national datasets.

\begin{tabular}{|c|c|c|c|c|c|c|}
\hline Province & $\begin{array}{l}\text { Plant available } \\
\text { water capacity } \\
\text { (mm) }\end{array}$ & $\begin{array}{l}\text { Bulk density } \\
\qquad\left(\mathrm{g} \mathrm{cm}^{-3}\right)\end{array}$ & $\begin{array}{l}\text { Wilting point } \\
(\mathrm{mm})\end{array}$ & $\begin{array}{l}\text { Nitrogen density } \\
\quad\left(\mathrm{g} \mathrm{cm}^{-2}\right)\end{array}$ & Planting date & $\begin{array}{c}\text { Nitrogen fertilizer } \\
\text { application at sowing } \\
\left(\mathrm{kg} \mathrm{ha}^{-1}\right)\end{array}$ \\
\hline Eastern Azarbaijan & 247.8 & 1.5 & 147.4 & 869.1 & 05 October & 10 \\
\hline Mazandaran & 245.4 & 1.4 & 150.2 & 1001.5 & 05 October & 70 \\
\hline Khuzestan & 248.4 & 1.7 & 155.8 & 698.9 & 05 October & 10 \\
\hline
\end{tabular}
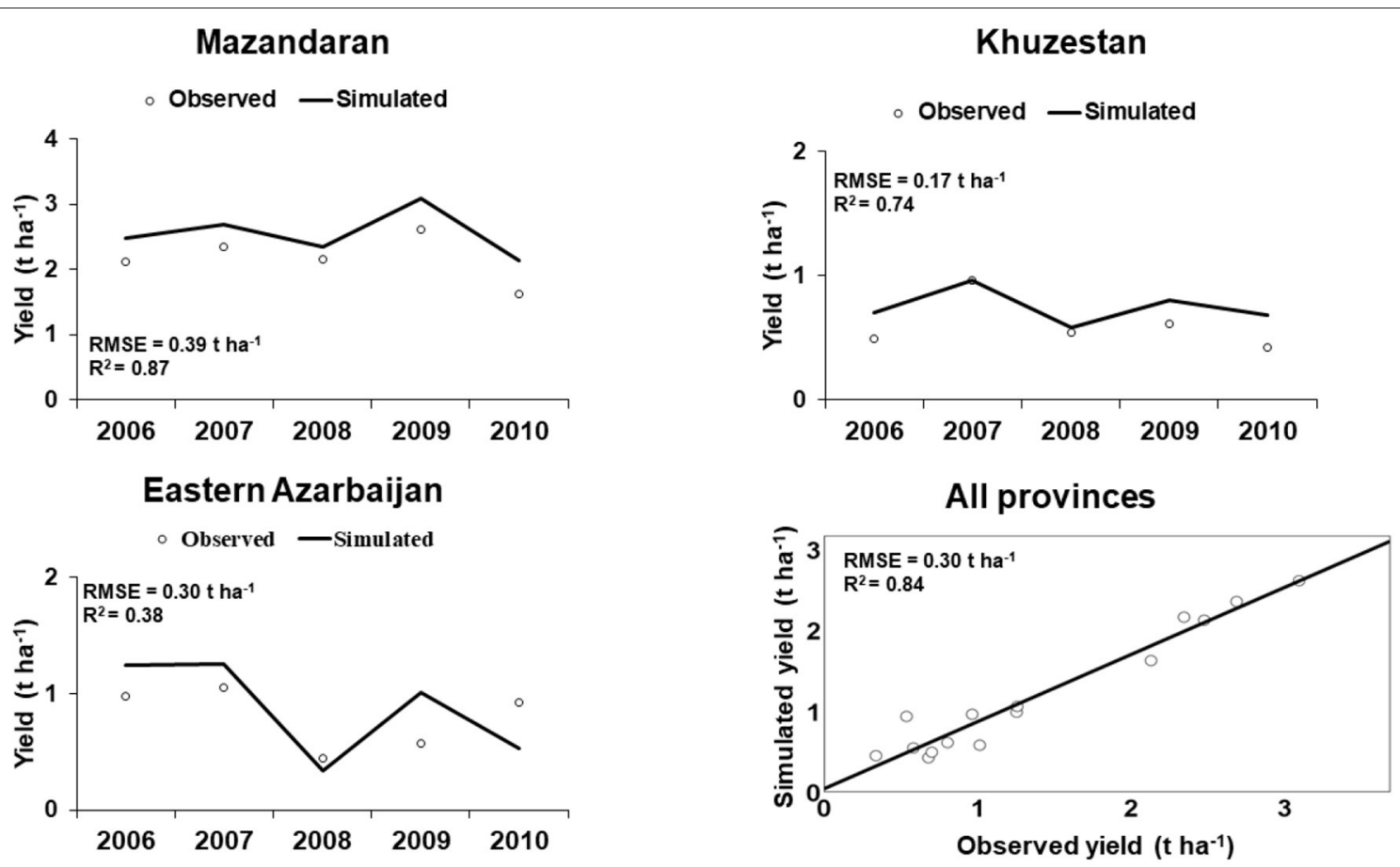

FIGURE 3 | Observed and simulated grain yield of rainfed wheat in each of the studied provinces of Iran and the 1:1 plot of all provinces for the period 2006-2010. The values represented are arithmetic mean. RMSE, root mean square error.

\section{DISCUSSION}

\section{Performance of the Crop Model}

Overall, the APSIM model efficiency in simulating the grain yield of rainfed wheat in the studied provinces was reasonably well. However, the model had lower accuracy in the cold semiarid province Eastern Azarbaijan than the temperate province Mazandaran and the hot arid province Khuzestan. This could be associated with frost events at the beginning of the growing season in Eastern Azarbaijan and not incorporating the frost damage into the simulation process, due to lack of data. It was already indicated that the crop model accuracy in simulating maize yield was low for the frost-prone regions of Iran (Eyshi Rezaei and Lashkari, 2019). Moreover, the simulated grain yields were overall slightly higher than the observed yields, probably due to lack of yield-limiting factors such as pests and diseases in the model. The current and other studies indicate that the APSIM model can be used to efficiently simulate the impacts of climate change on the grain yield of rainfed wheat in different climatic regions (Luo et al., 2009; Deihimfard et al., 2015).

\section{Climate Change Impact on the Growing Season Length and Grain Yield}

All climate change scenarios decreased the growing season length of rainfed wheat in all provinces. Further, the growing season length declined more by increasing temperature and reducing precipitation. Plants use various resources (e.g., sunlight, $\mathrm{CO}_{2}$, water, nutrients) and accumulate dry matter during their growing season. Therefore, environmental factors that can decrease the growing season length of a crop would disturb the utilization of these resources and would finally affect the crop's biomass accumulation and yield. One of the most important factors that can impact on the growing season length of plants is temperature. In wheat, increased temperatures enhance the crop's respiration rate and accelerate its development (Wiedenfeld, 2000; Tao et al., 2006). In general, $+1^{\circ} \mathrm{C}$ rise in temperature results in 5 days reduction in the growing season length of wheat (Lal et al., 1998; Fulco and Senthold, 2006; Bannayan and Eyshi Rezaei, 2014). This is in agreement with the declined growing season length by increasing temperature in the present study. Increased temperatures and reduced precipitation can also decline the 


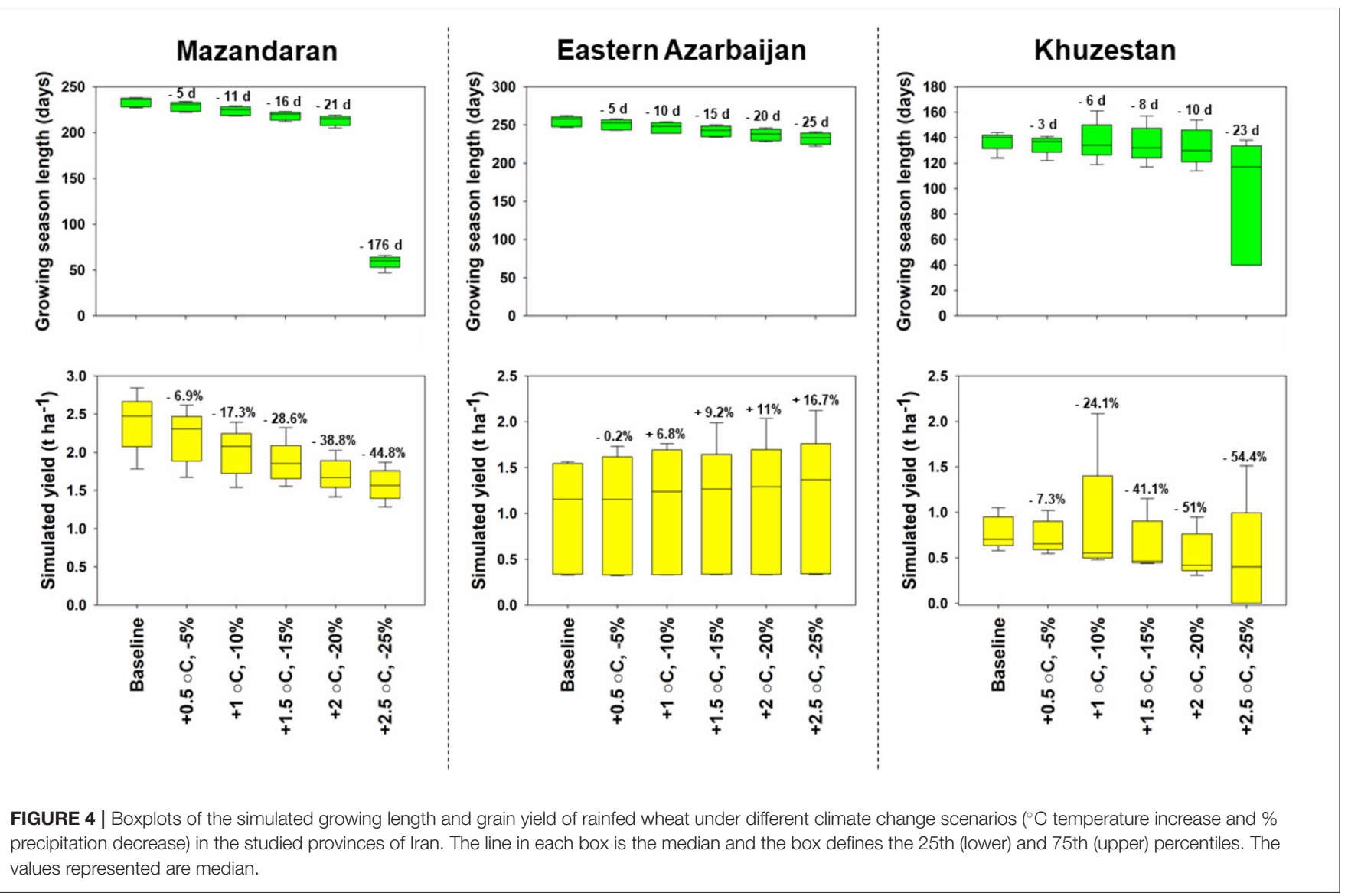

growing season length of wheat by causing heat stress and drought events at sensitive phenological stages of the crop such as flowering and grain-filling (Eitzinger et al., 2003; Fulco and Senthold, 2006; Valizadeh et al., 2014). Decline in the growing season length due to enhanced temperatures has been also reported for other important agronomic crops such as barley (Jones and Thornton, 2003) and rice (Prasad et al., 2006).

The grain yield declined in the temperate and hot arid provinces Mazandaran and Khuzestan under all climate change scenarios. However, the reduction magnitude was much greater under the higher temperature and lower precipitation scenarios. Precipitation is a key climatic factor for rainfed agroecosystems. The grain yield of rainfed wheat is significantly associated with precipitation amount and distribution under climate change (Rockstrom, 2003; Hernandez-Ochoa et al., 2018), especially in arid and semi-arid regions of the world like Iran (Tavakkoli and Oweis, 2004; Mirgol and Nazari, 2018). Precipitation reduction declines water availability to rainfed wheat and therefore decreases the grain yield (Bannayan and Eyshi Rezaei, 2014). Temperature is another important climatic factor for rainfed agroecosystems. Increased temperatures can affect the grain yield of cereal crops under rainfed conditions in different ways. One of the most important effects of increased temperatures on cereal crops is the reduction of the growing season length (Fulco and Senthold, 2006; Bannayan and Eyshi Rezaei, 2014; Eyshi Rezaei and Lashkari, 2019).
Declining wheat's growing season length means low radiation interception, eventually resulting in low biomass accumulation and grain yield (Eitzinger et al., 2003; Siebert and Ewert, 2012). In addition, increased temperatures can cause heat stress at the reproductive stages of cereals and significantly reduce the grain yield (Eyshi Rezaei et al., 2015). Increased temperatures can also damage the vernalization process at the beginning of the growing season in wheat and expose the crop to heat stress at its sensitive growth stages (Yan and Hunt, 1999; Bannayan and Eyshi Rezaei, 2014). Overall, the declined grain yields in the present study could be due to the scenarios of increased temperatures and reduced precipitation amounts, simultaneously. It is important to mention that the grain yield reduction was stronger in the hot arid province Khuzestan compared to the temperate province Mazandaran. This is in agreement with more severe yield reductions in arid regions of Iran under increased temperature scenarios (Eyshi Rezaei and Lashkari, 2019), demanding for specific attention to crop production management in such vulnerable areas.

In contrast to Mazandaran and Khuzestan, the grain yield mildly increased in the cold semi-arid province Eastern Azarbaijan under the climate change scenarios. Climate warming seems to be beneficial for improving the grain yield of rainfed wheat in cold regions like Eastern Azarbaijan. Wheat grown in cold regions is often limited by low temperatures (Fulco and Senthold, 2006). Therefore, increased temperatures in 


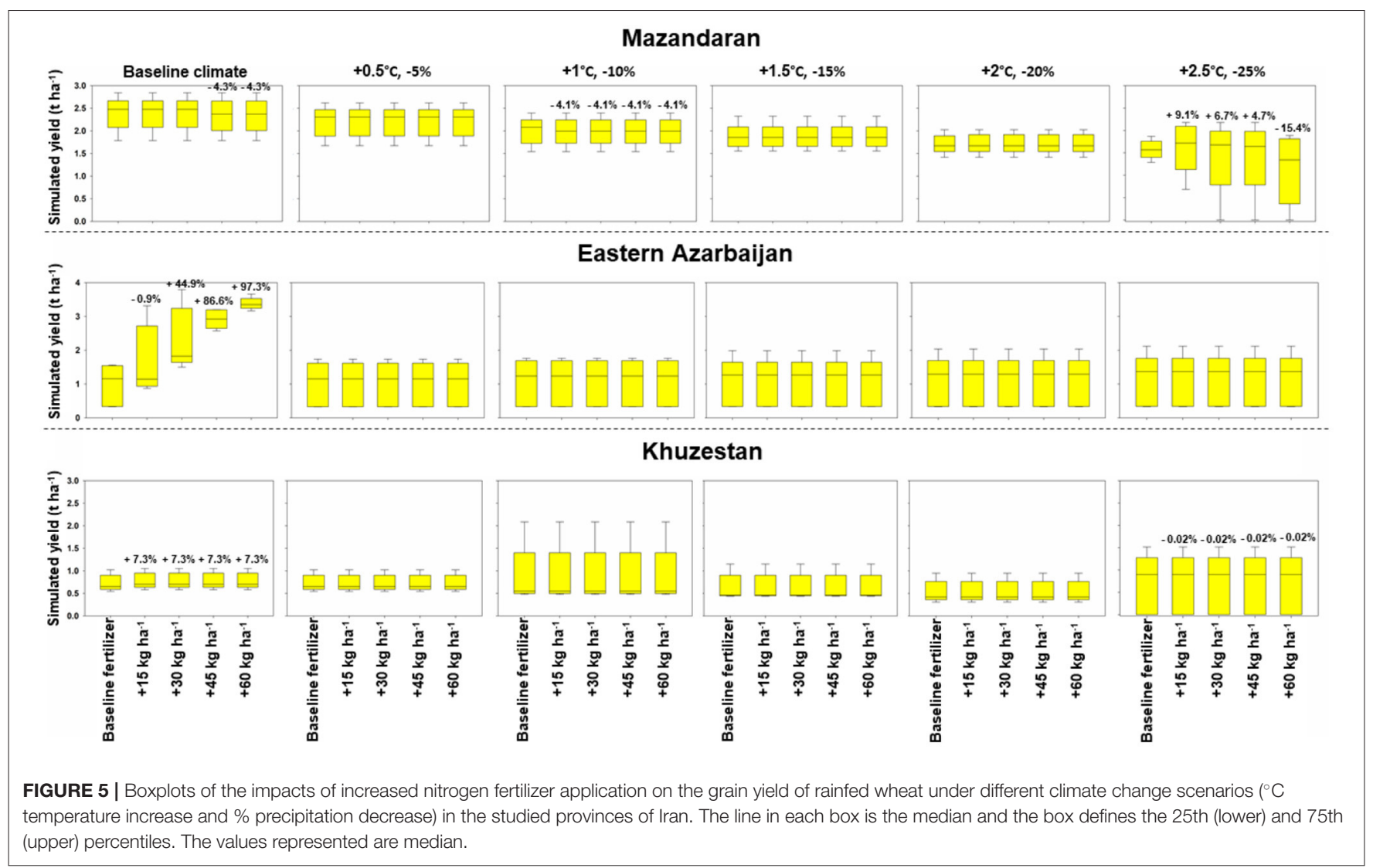

cold regions can improve flowering strength and grain yield of wheat (Fulco and Senthold, 2006; Challinor et al., 2007). Furthermore, increased temperatures in cold agroecosystems can result in an early ripening of rainfed wheat grains, helping the crop escape the late season heat stress (Ewert et al., 2005; Fulco and Senthold, 2006; Maddah et al., 2015).

\section{Impacts of Nitrogen Fertilizer Application on the Grain Yield}

Nitrogen is a substantial nutrient for growth and development of crops. However, crops require optimum conditions in order to use the available nitrogen proficiently. Water shortage is one of the most important reasons for the low nitrogen use efficiency of wheat (Ortiz-Monasterio, 2002; Guo et al., 2014; HernandezOchoa et al., 2018). In the present study, increasing the rate of nitrogen fertilizer application could not compensate for the grain yield reductions under the climate change scenarios in any of the provinces. This could be associated with water shortage caused by the increased temperatures and reduced precipitation scenarios. However, in the temperature province Mazandaran, the grain yield increased by $+9.1,+6.7$, and $+4.7 \%$ after adding $+15,+30$, and $+45 \mathrm{~kg} \mathrm{ha}^{-1}$ more nitrogen fertilizer, respectively, and decreased by $-15.4 \%$ after adding $60 \mathrm{~kg} \mathrm{ha}^{-1}$ more nitrogen fertilizer under the scenario $+2.5^{\circ} \mathrm{C}$ temperature plus - $25 \%$ precipitation. These enhancements might be due to accelerated crop growth by the increased temperatures, helping the crop have access to more precipitation water at its sensitive growth stages like flowering and grain-filling. It has already been reported that the grain yield of rainfed wheat in the semiarid regions of Iran is significantly correlated with precipitation in March (Mirgol and Nazari, 2018). In contrast, the declined grain yield could be attributed to reduced nitrogen use efficiency in wheat caused by the addition of extra nitrogen fertilizer to the soil (Zhang et al., 2012; Xu et al., 2020). In the provinces Eastern Azarbaijan and Khuzestan, the application of additional nitrogen fertilizer increased the grain yield considerably (by + 189\%) and mildly (by 7.6\%), respectively, under the baseline climatic conditions, implying the high capacity of these provinces to improve their rainfed wheat productivity through the application of low to moderate rates of nitrogen fertilizer. This is a rather low-cost strategy for farmers and the environment in these provinces, considering the currently very low $\left(10 \mathrm{~kg} \mathrm{ha}^{-1}\right)$ amounts of nitrogen fertilizer applied at sowing.

One of the sustainable solutions in order to improve the nitrogen use efficiency of rainfed wheat is the development of new cultivars (Foulkes et al., 2011; Hernandez-Ochoa et al., 2018). Combining new wheat cultivars with enhanced nitrogen fertilizer amounts was found to increase the grain yield of rainfed wheat (Ludwig and Asseng, 2010; Shiferaw et al., 2011). Another solution is to improve the crop's nitrogen availability without increasing the amount of nitrogen fertilizer, e.g., through applying partitioned amounts at different growth stages (Hernandez-Ochoa et al., 2018). Urea was the nitrogen 


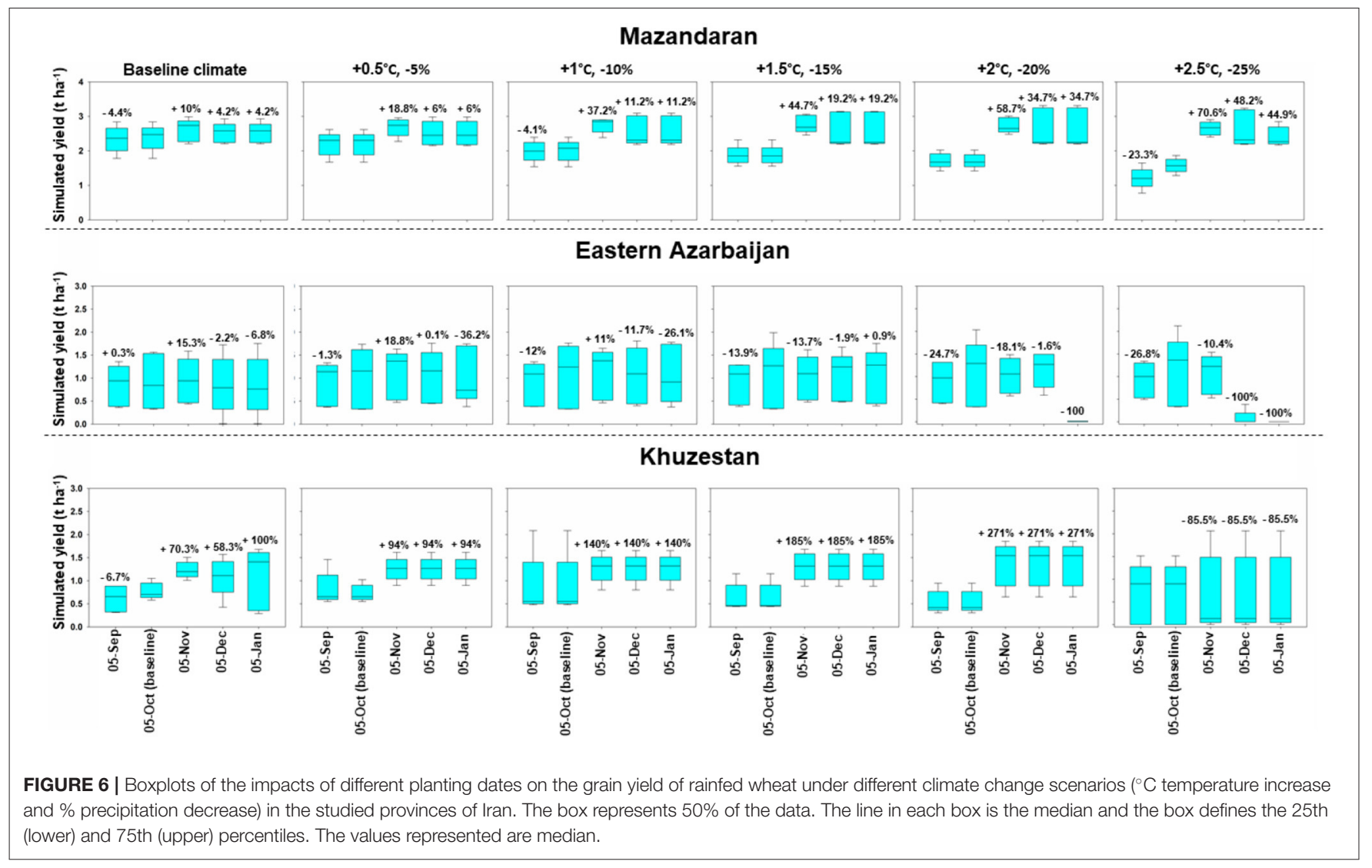

fertilizer used in the APSIM model in the present study. The application of another sort of nitrogen fertilizer with a slow nitrogen-releasing rate can be another option for increasing the nitrogen use efficiency and thereby the grain yield of rainfed wheat under climate change. Optimization of applied nitrogen fertilizer amount is so important, because high nitrogen fertilizer amounts coupled with improper wheat cultivar and climate change increase the risk of nitrogen leaching and can cause drastic environmental problems (Ju and Zhang, 2003; Yuan and Peng, 2017; Millar et al., 2018).

\section{Impacts of Planting Date on the Grain Yield}

Early planting in September had either no, neglectable, or negative impacts on the grain yield in all provinces. Rainfed wheat might not benefit from early planting under a changing climate due to high temperatures and low precipitation early in the growing season (Hernandez-Ochoa et al., 2018). Drought due to climate change in the early growing season may impair the vernalization process of rainfed wheat and expose the crop to heat stress at its sensitive growth stages. Moreover, drought in the early growing season can cause germination kill (a sort of crop failure) and lead to reduced grain yield (Nouri et al., 2017b).

Late planting in November, December, and January affected the grain yield in each province differently. In the temperate province Mazandaran, late planting in November, December, and January increased the grain yield $(+6$ to $+70.6 \%)$ under all climate change scenarios. Moreover, the enhancement magnitude increased by moving toward higher temperatures and lower precipitation amounts. In the hot arid province Khuzestan, grain yield was also increased $(+58.3$ to $+271 \%)$ through late planting in November, December, and January under all climate change scenarios except under the scenario $+2.5^{\circ} \mathrm{C}$ temperature plus - $25 \%$ precipitation which led to a yield reduction of $85.5 \%$. Precipitation deficit during the growing season of rainfed wheat is the most limiting factor for its production (Nouri et al., 2017b; Mirgol and Nazari, 2018). Most probably, late planting could match the crop's sensitive growth stages with the most optimum precipitation water availability under the changing climate. Delayed planting increased precipitation water availability to rainfed wheat at the growing stages germination to terminal spikelet initiation and at terminal spikelet initiation to end of leaf growth and also at beginning of ear growth, leading to improved crop establishment, development, and grain yield (Nouri et al., 2017b). Another reason for the increased grain yields by late planting could be the enhancement of leaf area index and transpiration to evapotranspiration ratio (Rockström and Falkenmark, 2000; Ferretti et al., 2003; Nouri et al., 2017b). This is crucially important in rainfed agriculture in which yield improvement through enhancing water use efficiency and transpiration to evapotranspiration ratio is intended (Rockström et al., 2010; Yang et al., 2015). Furthermore, late planting might have assisted the crop in escaping heat stress at its sensitive phenological phases (i.e., flowering and grain-filling), but this strategy may not be always desirable, because it led to 
considerable yield reductions in the hot arid province Khuzestan under the scenario $+2.5^{\circ} \mathrm{C}$ temperature plus $-25 \%$ precipitation.

In the cold semi-arid province Eastern Azarbaijan, only late planting in November increased the grain yield by + 18.8 and $11 \%$ under the climate change scenarios $+0.5^{\circ} \mathrm{C}$ temperature plus $-5 \%$ precipitation and $+1{ }^{\circ} \mathrm{C}$ temperature plus - $10 \%$ precipitation. Late planting dates in December and January declined the yield $(-1.6$ to $-100 \%)$ almost under all climate change scenarios in this province. It seems that late planting in December and January impairs seed germination and establishment of the crop and eventually reduces its grain yield, because these months are very cold and it is sometimes below the freezing point in this province.

\section{CONCLUSIONS}

This large-scale study was conducted to analyze the impacts of the different climate change scenarios on the grain yield of rainfed wheat for three provinces of contrasting climatic conditions in Iran. The climate change scenarios of increased temperatures and reduced precipitation declined the grain yield in the temperate and hot arid provinces Mazandaran and Khuzestan but increased it in the cold semi-arid province Eastern Azarbaijan. It is deduced that rainfed wheat production in regions with cold climates can benefit from the climate change, but it may be impaired in temperate regions and especially in vulnerable hot regions

\section{REFERENCES}

Abbaspour, K. C., Faramarzi, M., Ghasemi, S. S., and Yang, H. (2009). Assessing the impact of climate change on water resources in Iran. Water Resour. Res. 45, 1-16. doi: 10.1029/2008WR007615

Agricultural Ministry of Iran. (2010). Annual Statistics of Agricultural Production. Available online at: http://www.maj.ir (accessed: April 10, 2012)

Anwar, M. R., O’Leary, G., McNeil, D., Hossain, H., and Nelson, R. (2007). Climate change impact on rainfed wheat in south-eastern Australia. Field Crops Res. 104, 139-147. doi: 10.1016/j.fcr.2007.03.020

Bannayan, M., and Eyshi Rezaei, E. (2014). Future production of rainfed wheat in Iran (Khorasan province): climate change scenario analysis. Mitig. Adapt. Strateg. Glob. Chang. 19, 211-227. doi: 10.1007/s11027-0129435- $\mathrm{x}$

Bannayan, M., Mansoori, H., and Rezaei, E. E. (2014). Estimating climate change, $\mathrm{CO}_{2}$ and technology development effects on wheat yield in northeast Iran. Int. J. Biometeorol. 58, 395-405. doi: 10.1007/s00484-0130635-1

Batjes, N. H. (1995). A Homogenized Soil Data File for Global Environmental Research: A Subset of FAO, ISRIC, and NRCS Profiles (version 1.0). Work Pap Prepring 95/10b, Int Soil Ref Inf Center, Wageningen.

Brisson, N., Ruget, F., Gate, P., Lorgeouc, J., Nicoullauda, B., Tayot, X., et al. (2002). STICS: a generic model for simulating crops and their water and nitrogen balances. II. Model validation for wheat and maize. Agronomie 22, 69-92. doi: 10.1051/agro:2001005

Challinor, A. J., Watson, J., Lobell, D. B., Howden, S. M., Smith, D. R., and Chhetri, N. (2014). A meta-analysis of crop yield under climate change and adaptation. Nat. Clim. Chang. 4, 287-291. doi: 10.1038/nclimate2153

Challinor, A. J., Wheeler, T. R., Craufurd, P. Q., Ferro, C. A. T., and Stephenson, D. B. (2007). Adaptation of crops to climate change through genotypic responses to mean and extreme temperatures agriculture. Ecosyst. Environ. 119, 190-204. doi: 10.1016/j.agee.2006.07.009 like Khuzestan. Not only is not the application of additional nitrogen fertilizer at planting a good adaptive strategy in order to compensate for rainfed wheat yield reduction under the climate change, but it can also endanger environmental health and sustainability. As an alternative, shifting planting date can be considered a desirable yield-compensating and environmentally friendly adaptive strategy against climate change in temperate and hot arid regions.

\section{DATA AVAILABILITY STATEMENT}

The raw data supporting the conclusions of this article will be made available by the authors, without undue reservation.

\section{AUTHOR CONTRIBUTIONS}

MN conducted the modeling processes by APSIM and prepared the manuscript draft. BM and HS obtained the data and designed the maps. All authors read the manuscript and commented on it before submission.

\section{ACKNOWLEDGMENTS}

The German Federal Environmental Foundation (Deutsche Bundesstiftung Umwelt, DBU) is acknowledged for funding MN during the preparation of the manuscript.

Degener, J. F. (2015). Atmospheric CO 2 fertilization effects on biomass yields of 10 crops in northern Germany. Front. Environ. Sci. 3:48. doi: $10.3389 /$ fenvs.2015.00048

Deihimfard, R., Mahallati, M. N., and Koocheki, A. (2015). Yield gap analysis in major wheat growing areas of Khorasan province, Iran, through crop modelling. Field Crops Res. 184, 28-38. doi: 10.1016/j.fcr.2015.09.002

Dinpashoh, Y., Jhajharia, D., Fakheri-Fard, A., Singh, V. P., and Kahya, E. (2011). Trends in reference crop evapotranspiration over Iran. J. Hydrol. 399, 422-433. doi: 10.1016/j.jhydrol.2011.01.021

Eitzinger, J., Stastna, M., Zalud, Z., and Dubrovsky, M. (2003). A simulation study of the effect of soil water balance and water stress on winter wheat production under different climate change scenarios. Agric. Water Manage. 61, 195-217 doi: 10.1016/S0378-3774(03)00024-6

Evans, J. P. (2009). 21st century climate change in the Middle East. Clim. Chang. 92, 417-432. doi: 10.1007/s10584-008-9438-5

Ewert, F., Rounsevell, M. D. A., Reginster, I., Metzger, M. G., and Leemans, R. (2005). Future scenarios of European agricultural land use. I. Estimating changes in crop productivity. Agric. Ecosyst. Environ. 107, 101-116. doi: 10.1016/j.agee.2004.12.003

Eyshi Rezaei, E., and Lashkari, A. (2019). The consequences of change in management practices on maize yield under climate warming in Iran. Theor. Appl. Climatol. 137, 1001-1013. doi: 10.1007/s00704-018-2637-8

Eyshi Rezaei, E., Siebert, S., and Ewert, F. (2017). Climate and management interaction cause diverse crop phenology trends. Agric. For. Meteorol. 233, 55-70. doi: 10.1016/j.agrformet.2016.11.003

Eyshi Rezaei, E., Webber, H., Gaiser, T., Naab, J., and Ewert, F. (2015). Heat stress in cereals: mechanisms and modelling. Eur. J. Agron. 64, 98-113. doi: 10.1016/j.eja.2014.10.003

Eyshi Rezaie, E., and Bannayan, M. (2012). Rainfed wheat yields under climate change in northeastern Iran. Meteorol. Appl. 19, 346-354. doi: 10.1002/met.268

Faramarzi, M., Yang, H., Schulin, R., and Abbaspour, K. C. (2010). Modeling wheat yield and crop water productivity in Iran: implications of agricultural 
water management for wheat production. Agric. Water Manage. 97, 1861-1875. doi: 10.1016/j.agwat.2010.07.002

Ferretti, D., Pendall, E., Morgan, J., Nelson, J., Lecain, D., and Mosier, A. (2003). Partitioning evapotranspiration fluxes from a Colorado grassland using stable isotopes: seasonal variations and ecosystem implications of elevated atmospheric CO2. Plant Soil 254, 291-303. doi: 10.1023/A:1025511618571

Foltz, R. C. (2002). Iran's water crisis: cultural, political, and ethical dimensions. J. Agric. Environ. Ethics 15, 357-380. doi: 10.1023/A:1021268621490

Foulkes, M. J., Slafer, G. A., Davies, W. J., Berry, P. M., Sylvester-Bradley, R., Martre, P., et al. (2011). Raising yield potential of wheat. III. Optimizing partitioning to grain while maintaining lodging resistance. J. Exp. Bot. 62, 469-486. doi: 10.1093/jxb/erq300

Fulco, L. A., and Senthold, A. (2006). Climate change impacts on wheat production in a Mediterranean environment in Western Australia. Agric. Syst. 90, 159-179. doi: 10.1016/j.agsy.2005.12.002

Giannakopoulos, C., Le Sager, P., Bindi, M., Moriondod, M., Kostopoulou, E., Goodess, C. M. (2009). Climatic changes and associated impacts in the Mediterranean resulting from a $2^{\circ} \mathrm{C}$ global warming. Glob. Planet Chang. 68, 209-224. doi: 10.1016/j.gloplacha.2009.06.001

Guo, Z., Zhang, Y., Zhao, J., Shi, Y., and Yu, Z. (2014). Nitrogen use by winter wheat and changes in soil nitrate nitrogen levels with supplemental irrigation based on measurement of moisture content in various soil layers. Field Crops Res. 164, 117-125. doi: 10.1016/j.fcr.2014.05.016

Hajarpoor, A. (2014). Simulating climate change impacts on production of chickpea under water-limited conditions. Agric. Sci. Dev. 3, 209-217.

Hartmann, D. L., Tank, M. G. K., and Rusticucci, M. (2013). IPCC Fifth Assessment Report, Climatie Change 2013: The Physical Science Basis.

Hernandez-Ochoa, I. M., Asseng, S., Kassie, B. T., Xiong, W., Robertson, R., Luz Pequeno, D. N., et al. (2018). Climate change impact on Mexico wheat production. Agric. For. Meteorol. 263, 373-387. doi: 10.1016/j.agrformet.2018.09.008

Hijmans, R. J. (2003). The effect of climate change on global potato production. Am. J. Potato. Res. 80, 271-279. doi: 10.1007/BF02855363

Holzworth, D. P., Huth, N. I., deVoil, P. G., Zurcher, E. J., Herrmann, N. I., McLean, G., et al. (2014). "APSIM - evolution towards a new generation of agricultural systems simulation.” Environ. Model. Softw. 62, 327-350. doi: 10.1016/j.envsoft.2014.07.009

Jones, P. G., and Thornton, P. K. (2003). The potential impacts of climate change on maize production in Africa and Latin America in 2055. Glob. Environ. Change 13, 51-59. doi: 10.1016/S0959-3780(02)00090-0

Ju, X., and Zhang, F. (2003). Nitrate accumulation and its implication to environment in north China. Ecol. Environ. 12, 24-38.

Kottek, M., Grieser, J., Beck, C., Rudolf, B., and Rubel, F. (2006). World Map of the Köppen-Geiger climate classification updated. Meteorologische Z. 15, 259-263. doi: 10.1127/0941-2948/2006/0130

Kousari, M. R., Ahani, H., and Hendi-zadeh, R. (2013). Temporal and spatial trend detection of maximum air temperature in Iran during 1960-2005. Glob. Planet Change 111, 97-110. doi: 10.1016/j.gloplacha.2013.08.011

Lal, M., Singh, K. K., Rathore, L. S., Srinivasan, G., and Saseendran, S. A. (1998). Vulnerability of rice and wheat yields in NW India to future changes in climate. Agric. For. Meteorol. 89, 101-114. doi: 10.1016/S0168-1923(97)0 0064-6

Lashkari, A., Alizadeh, A., Rezaei, E. E., and Bannayan, M. (2012). Mitigation of climate change impacts on maize productivity in northeast of Iran: a simulation study. Mitig. Adapt. Strateg. Glob. Change 17, 1-16. doi: 10.1007/s11027-011-9305-y

Liu, B., Asseng, S., Müller, C., Ewert, F., Elliott, J., Lobell, D. B., et al. (2016). Similar estimates of temperature impacts on global wheat yield by three independent methods. Nat. Clim. Chang. 6:1130-1136. doi: 10.1038/nclimate3115

Lobell, D. B., Burke, M. B., Tebaldi, C., Mastrandrea, M. D., Falcon, W. P., and Naylor, R. L. (2008). Prioritizing climate change adaptation need for food security in 2030. Science 319, 607-610. doi: 10.1126/science.1152339

Lobell, D. B., Schlenker, W., and Costa-Roberts, J. (2011). Climate trends and global crop production since 1980. Science 333, 616-620. doi: $10.1126 /$ science. 1204531

Ludwig, F., and Asseng, S. (2010). Potential benefits of early vigor and changes in phenology in wheat to adapt to warmer and drier climates. Agric. Syst. 103, 127-136. doi: 10.1016/j.agsy.2009.11.001
Luo, Q., Bellotti, W., Williams, M., and Wang, E. (2009). Adaptation to climate change of wheat growing in South Australia: analysis of management and breeding strategies. Agri. Ecosyst. Environ. doi: 10.1016/j.agee.2008.09.010

Maddah, V., Soltani, A., Zeinali, E., and Bannayan-Aval, M. (2015). Simulating climate change impacts on wheat production in Gorgan, Iran. Bull. Environ. Pharmacol. Life Sci. 4, 58-67.

McNunn, G., Heaton, E., Archontoulis, S., Licht, M., and VanLoocke, A. (2019). Using a crop modeling framework for precision cost-benefit analysis of variable seeding and nitrogen application rates. Front. Sustain. Food Syst. 3:108. doi: 10.3389/fsufs.2019.00108

Millar, N., Urrea, A., Kahmark, K., Shcherbak, I., Robertson, G. P., and OrtizMonasterio, I. (2018). Nitrous oxide (N2O) flux responds exponentially to nitrogen fertilizer in irrigated wheat in the yaqui Valley, Mexico. Agric. Ecosyst. Environ. 261, 125-132. doi: 10.1016/j.agee.2018.04.003

Mirgol, B., and Nazari, M. (2018). Possible scenarios of winter wheat yield reduction of Dryland Qazvin Province, Iran, based on prediction of temperature and precipitation till the end of the century. Climate. 6:78. doi: $10.3390 /$ cli6040078

Mirgol, B., Nazari, M., and Eteghadipour, M. (2020). Modelling climate change impact on irrigation water requirement and yield of winter wheat (Triticum aestivum L.), barley (Hordeum vulgare L.), and Fodder Maize (Zea mays L.) in the semi-arid Qazvin plateau, Iran. Agriculture. 10:60. doi: 10.3390/agriculture10030060

Mitchell, R. A. C., Mitchell, V. J., Driscoll, S. P., Franklin, J., and Lawlor, D. W. (1993). Effects of increased CO2 concentration and temperature on growth and yield of winter wheat at two levels of nitrogen application. Plant Cell Environ. 16, 521-529. doi: 10.1111/j.1365-3040.1993.tb00899.x

Moradi, R., Koocheki, A., Nassiri Mahallati, M., and Mansoori, H. (2013). Adaptation strategies for maize cultivation under climate change in Iran: irrigation and planting date management. Mitig. Adapt. Strateg. Glob. Change 18, 265-284. doi: 10.1007/s11027-012-9410-6

Nassiri, M., Koocheki, A., Kamali, G. A., and Shahandeh, H. (2006). Potential impact of climate change on rainfed wheat production in Iran. Arch. Agron. Soil Sci. 52, 113-124. doi: 10.1080/03650340600560053

Nazari Nooghabi, S., Fleskens, L., Sietz, D., and Azadi, H. (2020). Typology of vulnerability of wheat farmers in Northeast Iran and implications for their adaptive capacity. Clim. Dev. 12, 703-716. doi: 10.1080/17565529.2019.1679072

Nouri, M., Homaee, M., and Bannayan, M. (2017a). Climate variability impacts on rainfed cereal yields in west and northwest Iran. Int. J. Biometeorol. 61, 1571-1583. doi: 10.1007/s00484-017-1336-y

Nouri, M., Homaee, M., Bannayan, M., and Hoogenboom, G. (2017b). Towards shifting planting date as an adaptation practice for rainfed wheat response to climate change. Agric. Water Manage. 186, 108-119. doi: 10.1016/j.agwat.2017.03.004

Ortiz, R., Sayre, K. D., Govaerts, B., Gupta, R., Subbarao, G. V., Ban, T., et al. (2008). Climate change: can wheat beat the heat? Agric. Ecosyst. Environ. 126, 46-58. doi: 10.1016/j.agee.2008.01.019

Ortiz-Monasterio, J. I. (2002). "Nitrogen management in irrigated spring wheat," in Bread Wheat: Improvement and Production, eds B. C. Curtis, S. Rajaram, H. Gomez-Macpherson (Rome: Food and Agriculture Organization of the United Nations) ,554.

Parry, M. L., Rosenzweig, C., Iglesias, A., Livermore, M., Fischer, G. (2004). Effects of climate change on global food production under SRES emissions and socioeconomic scenarios. Glob. Environ. Chang. 14, 53-67. doi: 10.1016/j.gloenvcha.2003.10.008

Prasad, P. V. V., Boote, K. J., Allen, L. H., Sheehy, J. E., Thomas, J. M. G. (2006). Species, ecotype and cultivar differences in spikelet fertility and harvest index of rice in response to high temperature stress. Field Crops Res. 95, 398-411. doi: 10.1016/j.fcr.2005.04.008

Ray, D. K., Gerber, J. S., MacDonald, G. K., West, P. C. (2015). Climate variation explains a third of global crop yield variability. Nat. Commun. 6:5989. doi: 10.1038/ncomms6989

Rienecker, M. M., Suarez, M. J., Gelaro, R., Todling, R., Bacmeister, J., Liu, E., et al. (2011). MERRA: NASA's modern-era retrospective analysis for research and applications. J. Clim. 24, 3624-3648. doi: 10.1175/JCLI-D-11-00015.1

Rockstrom, J. (2003). Water for food and nature in drought-prone tropics: vapor shift in rain -fed agriculture. Philos. Trans. R. Soc. 358, 1997-2009. doi: $10.1098 /$ rstb.2003.1400 
Rockström, J., and Falkenmark, M. (2000). Semiarid crop production from a hydrological perspective: gap between potential and actual yields. Crit. Rev. Plant Sci. 19, 319-346. doi: 10.1080/07352680091139259

Rockström, J., Karlberg, L., Wani, S. P., Barron, J., Hatibu, N., Oweis, T., et al. (2010). Managing water in rainfed agriculture-the need for a paradigm shift. Agric. Water Manag. 97, 543-550. doi: 10.1016/j.agwat.2009.09.009

Rojas, M., Lambert, F., Ramirez-Villegas, J., and Challinor, A. J. (2019). Emergence of robust precipitation changes across crop production areas in the 21st century. Proc. Natl. Acad. Sci. U.S.A. 116, 6673-8. doi: $10.1073 /$ pnas. 1811463116

Ruane, A. C., Goldberg, R., and Chryssanthacopoulos, J. (2015). Climate forcing datasets for agricultural modeling: merged products for gap-filling and historical climate series estimation. Agric. For. Meteorol. 200, 233-248. doi: 10.1016/j.agrformet.2014.09.016

Saboohi, R., Soltani, S., and Khodagholi, M. (2012). Trend analysis of temperature parameters in Iran. Theor. Appl. Climatol. 109, 529-547. doi: $10.1007 /$ s00704-012-0590-5

Sakurai, G., Iizumi, T., and Yokozawa, M. (2011). Varying temporal and spatial effects of climate on maize and soybean affect yield prediction. Clim. Res. 49, 143-154. doi: 10.3354/cr01027

Sayari, N., Bannayan, M., Alizadeh, A., Farid, A., Hessami Kermani, M. R., and Eyshi Rezaei, E. (2015). Climate change impact on legumes' water production function in the northeast of Iran. J. Water Clim. Chang. 6, 374-385. doi: $10.2166 /$ wcc. 2014.139

Schlenker, W., and Lobell, D. B. (2010). Robust negative impacts of climate change on African agriculture. Environ. Res. Lett. 5:014010. doi: 10.1088/1748-9326/5/1/014010

Shiferaw, B., Prasanna, B. M., Hellin, J., and Banziger, M. (2011). Crops that feed the world 6. Past successes and future challenges to the role played by maize in global food security. Food Secur. 3, 307-327. doi: 10.1007/s12571-011-0140-5

Siebert, S., and Ewert, F. (2012). Spatio-temporal patterns of phenological development in Germany in relation to temperature and day length. Agric. for. Meteorol. 152, 44-57. doi: 10.1016/j.agrformet.2011.08.007

Tao, F., Yokozawa, M., Liu, J., and Zhang, Z. (2008). Climate-crop yield relationships at provincial scales in China and the impacts of recent climate trends. Clim. Res. 38, 83-94. doi: 10.3354/cr00771

Tao, F., Yokozawa, M., Xu, Y., Hayashi, Y., and Zhang, Z. (2006). Climate changes and trends in phenology and yields of field crops in China, 1981-2000. Agric. For. Meteorol. 138, 82-92 doi: 10.1016/j.agrformet.2006.03.014

Tavakkoli, A. R., and Oweis, T. Y. (2004). The role of supplemental irrigation and nitrogen in producing bread wheat in the highlands of Iran. Agric. Water Manage. 65, 225-236. doi: 10.1016/j.agwat.2003.09.001

Teixeira, E. I., Fischer, G., van Velthuizen, H., Walter, C., and Ewert, F. (2013). Global hot-spots of heat stress on agricultural crops due to climatechange. Agric. For. Meteorol. 170, 206-215. doi: 10.1016/j.agrformet.2011.09.002

Urwin, K., and Jordan, A. (2008). Does public policy support or undermine climate change adaptation? Exploring policy interplay across different scales of governance. Glob. Environ. Chang. 18, 180-191. doi: 10.1016/j.gloenvcha.2007.08.002
Vaghefi, S. A., Keykhai, M., Jahanbakhshi, F., Sheikholeslami, J., Ahmadi, A., Yang, H., et al. (2019). The future of extreme climate in Iran. Sci. Rep. 9:1464. doi: 10.1038/s41598-018-38071-8

Valizadeh, J., Ziaei, S. M., and Mazloumzadeh, S. M. (2014). Assessing climate change impacts on wheat production (a case study). J. Saudi Soc. Agric. Sci. 13, 107-115. doi: 10.1016/j.jssas.2013. 02.002

Vallam, P., and Qin, X. S. (2018). Projecting future precipitation and temperature at sites with diverse climate through multiple statistical downscaling schemes. Theor. Appl. Climatol. 134, 669-688. doi: 10.1007/s00704-0172299-y

Wiedenfeld, R. P. (2000). Water stress during different sugarcane growth periods on yield and response to $\mathrm{N}$ fertilization. Agric. Water Manage. 43, 173-182. doi: 10.1016/S0378-3774(99)00053-0

Xu, A., Li, L., Xie, J., Wang, X., Coulter, J. A., Liu, C., et al. (2020). Effect of longterm nitrogen addition on wheat yield, nitrogen use efficiency, and residual soil nitrate in a semiarid area of the Loess Plateau of China. Sustainability 12:1735. doi: $10.3390 /$ su12051735

Yan, W., and Hunt, L. A. (1999). Reanalysis of vernalization data of wheat and carrot. Ann. Bot. 84, 615-619. doi: 10.1006/anbo.1999.0956

Yang, Y., Li Liu, D., Anwar, M. R., O’Leary, G., Macadam, I., and Yang, Y. (2015). Water use efficiency and crop water balance of rainfed wheat in a semi-arid environment: sensitivity of future changes to projected climate changes and soil type. Theor. Appl. Climatol. 123, 565-579. doi: 10.1007/s00704-015-1376-3

Yuan, S., and Peng, S. (2017). Exploring the trends in nitrogen input and nitrogen use efficiency for agricultural sustainability. Sustainability 9:1905. doi: $10.3390 /$ su9101905

Zhang, F., Cui, Z., Chen, X., Ju, X., Shen, J., Chen, Q., et al. (2012). Integrated nutrient management for food security and environmental quality in China. Adv. Agron. 116, 1-40. doi: 10.1016/B978-0-12-394277-7.00001-4

Conflict of Interest: The authors declare that the research was conducted in the absence of any commercial or financial relationships that could be construed as a potential conflict of interest.

Publisher's Note: All claims expressed in this article are solely those of the authors and do not necessarily represent those of their affiliated organizations, or those of the publisher, the editors and the reviewers. Any product that may be evaluated in this article, or claim that may be made by its manufacturer, is not guaranteed or endorsed by the publisher.

Copyright (c) 2021 Nazari, Mirgol and Salehi. This is an open-access article distributed under the terms of the Creative Commons Attribution License (CC BY). The use, distribution or reproduction in other forums is permitted, provided the original author(s) and the copyright owner(s) are credited and that the original publication in this journal is cited, in accordance with accepted academic practice. No use, distribution or reproduction is permitted which does not comply with these terms. 